\title{
Autologous blood as tissue adhesive for conjunctival autograft in primary nasal pterygium surgery
}

\author{
Kiran Beesam ${ }^{1}$, Krishna N ${ }^{1}$ \\ ${ }^{1}$ Nizamabad Medical College, Nizamabad, Telengana, India \\ Beesam K, Krishna N. Autologous blood as tissue adhesive for conjunctival autograft in primary nasal pterygium surgery. J Pre-Clin Clin Res. \\ 2018; 12(2): 51-53. doi: 10.26444/jpccr/92090
}

\begin{abstract}
Introduction. Pterygium is defined as a triangular fibrovascular growth of connective tissue covered with conjunctival epithelium which extends over the corneal surface from the corneo-scleral margin. Surgical removal is the mainstay treatment with autologous blood used as tissue adhesive to prevent recurrences and scarring.

Objectives. To describe a simple method of conjunctival autograft adherence during pterygium surgery, and assess the efficacy of securing limbal conjunctival autograft using the patient's own blood.

Materials and method. This is a prospective interventional study conducted from June 2017 - March 2018 in the department of Ophthalmology at the Government Medical College in Nizamabad, India. After pterygium excision, conjunctival autograft was placed over the sclera bed after attaining haemostasis. Graft adherence was examined 20 minutes after surgery.

Results. A total 100 patients with pterygium underwent pterygium excision with conjunctival autograft surgery using autologous blood. There were 45 female and 55 male patients who had primary nasal pterygium, and 65 patients with progressive pterygium and 35 patients with non-progressive pterygium. Post-operative complications like granuloma had developed in $3(3 \%)$ patients, 10 (10\%) patients had conjunctival haemorrhage, 5 (5\%) patients had developed graft dehiscence and retraction. 4 (4\%) patients had graft oedema and 2 (2\%) patients developed recurrence of pterygium after 3 months. Improvement of visual acuity was observed in 10 patients. Cosmesis was good in all patients

Conclusions. It could be concluded from this study that using autologous blood as a tissue adhesive for graft fixation is a useful alternative. This procedure is safe, effective, and economical, with less discomfort and more patient satisfaction. Risks associated with fibrin glue and suture related problems are avoided.
\end{abstract}

\section{Key words}

primary pterygium, conjunctival graft, autologous blood, graft adherence

\section{INTRODUCTION}

Pterygium is defined as a triangular fibrovascular growth of connective tissue covered with conjunctival epithelium which extends over the corneal surface from the corneoscleral margin [1]. The word 'pterygium' is derived from the Greek word 'pterygos', meaning 'wing' $[2,3]$. Pterygium is a degenerative condition of the subconjunctival tissue which proliferates as vascularised granulation tissue to invade the cornea, destroying the superficial layers of the stroma and bowman's membrane, the whole being covered by conjunctival epithelium. It appears as a triangular encroachment of the conjunctiva upon the cornea. Prevalance of pterygium is high in the tropical belt of the world, especially in india where hot, sunny and dusty weather favours its growth $[3,4]$, UV rays are the most important risk factor [5, 6]. Small pterygium usually gives no symptoms, but large pterygia can be an indication for pterygium excision, because of decreased visual acuity resulting from visual axis involvement, irregular astigmatism, tear film break up, and/or irregular eye movement limitation, eye irritation and discomfort, inability to wear contact lenses, difficulty in performing refractive surgery and cosmetic concern [7]

Address for correspondence: Kiran Beesam, Nizamabad Medical College, Flat 312, near Indian bank, Attapur, pillar No. 118, 500048 Hyderabad, India

E-mail: kiranbisam141@gmail.com

Received: 4 May 2018; accepted: 8 June 2018
Surgical removal remains the mainstay treatment, the basic procedure being complete excision leaving a bare area of sclera. The recurrence rate of traditional bare sclera technique ranges from $24 \%-89 \%$ [8]; therefore, only the use of adjuvant treatment is justified to tackle this problem. Among the various modalities in use are: beta irradiation, intraoperative application of mitomycin-c conjunctival auto graft and amniotic membrane graft. Conjunctival autografting has been a method to reduce recurrence following pterygium.

\section{MATERIALS AND METHOD}

From patients with primary nasal pterygium fulfilling the inclusion and exclusion criteria, attending the outpatient department of Ophthalmology at the Governament Medical College, in Nizamabad, India, 100 patients with nasal pterygium were selected for the study. This was a prospective interventional study conducted over a period of 10 months, from June 2017 - March 2018. Inclusion criteria: diminution of vision, either because of astigmatism or encroachment on the pupillary area; nasaal pterygium; patients of either gender; age group of 20-50 yrs. Exclusion criteria: recurrent / temporal / atrophic pterygium; patients on anticoagulants; blepharitis, dry eyes; H/o previous occular surgery or trauma; Pterygium with cystic degeneration; pseudopterygium.

All surgical procedures were performed by the same surgeon after routine blood investigations. Operations were 
performed under peribulbar anaesthesia using a $2 \%$ xylocaine injection. The body of the pterygium was dissected $4 \mathrm{~mm}$ from the limbus, down to the bare sclera. Blunt and sharp dissection by Wescott scissors was performed for separating fibrovascular tissue from the surrounding conjunctiva. The pterygium was removed from the cornea (superficial keratectomy) using a crescent knife. Only thickened portions of conjunctiva and the immediate adjacent and subjacent tenon's capsule showing tortuous vasculature were excised.

The recipient bed was measured with castoveijo callipers, and a graft size of at least $1 \mathrm{~mm}$ larger was aimed at. The average graft size was $5-6 \mathrm{~mm}$ in all the cases. From the superotemporal quadrant, a thin conjunctival autograft was dissected free of tenon's and without buttonholing. The graft was then pulled on to the cornea, taking care to prevent it from getting rolled over, to maintain epithelial side up orientation. Bleeders were either not cauterised at all, or only minimal cautery was performed if required.

After excision of the pterygium, blood was allowed to collect in the bare recipient scleral bed for 1-2 min. The free CAG was applied over the bare recipient bed, spread and held in position for $5 \mathrm{~min}$ until, in most cases, firm setting of the autologous fibrin occurred, ensuring graft adhesion. While waiting for the adhesion, care was taken to ensure that excessive and prolonged bleeding did not displace the graft from the bed, and residual active haemorrhage beneath the graft, if any, was tamponaded by direct compression with a blunt instrument. Graft adherence was confirmed at the end of the procedure, antibiotic eye ointment applied and a pressure bandage was given for $24 \mathrm{hrs}$.

Routine postoperative therapy consisted of $0.5 \%$ moxifloxacin eye drops every $6 \mathrm{~h}$ for 6 weeks, $1 \%$ prednisolone acetate eye drops every $4 \mathrm{~h}$ for 1 week, to be tapered over a month, and lubricant eye drops every $4 \mathrm{~h}$ for 1 month. Patients were followed up post-operatively on dayl, then week 1 , month 1 , and 3 months and 6 months. At each visit, a slit lamp examination was performed to assess the graft adherence, displacement or retraction, and the presence of recurrence or any other untoward effect.

\section{RESULTS}

A total 100 patients with pterygium underwent pterygium excision with conjunctival autograft surgery using autologous blood (Fig. 1). There were 45 females and 55 males and patients had primary nasal pterygium, 65 patients with nonprogressive pterygium and 35 patients with non-progressive pterygium There were no intra-operative complications noted (Fig. 2, 3, 4, 5). Post-operative complications, e.g. granuloma (Fig. 6), had developed in 3 (3\%) patients, 10 (10\%) patients had conjunctival haemorrhage (Fig. 7), 5 (5\%) patients had developed graft dehiscence and retraction, $2(2 \%)$ patients had graft oedema and 5 (5\%) patients developed recurrence of pterygium after 3 months. Improvement of visual acuity was seen in 10 patients.

\section{DISCUSSION}

Pterygium is a common external ocular disease seen in tropical countries like India. The only effective treatment for pterygium is surgery. Surgical techniques for the

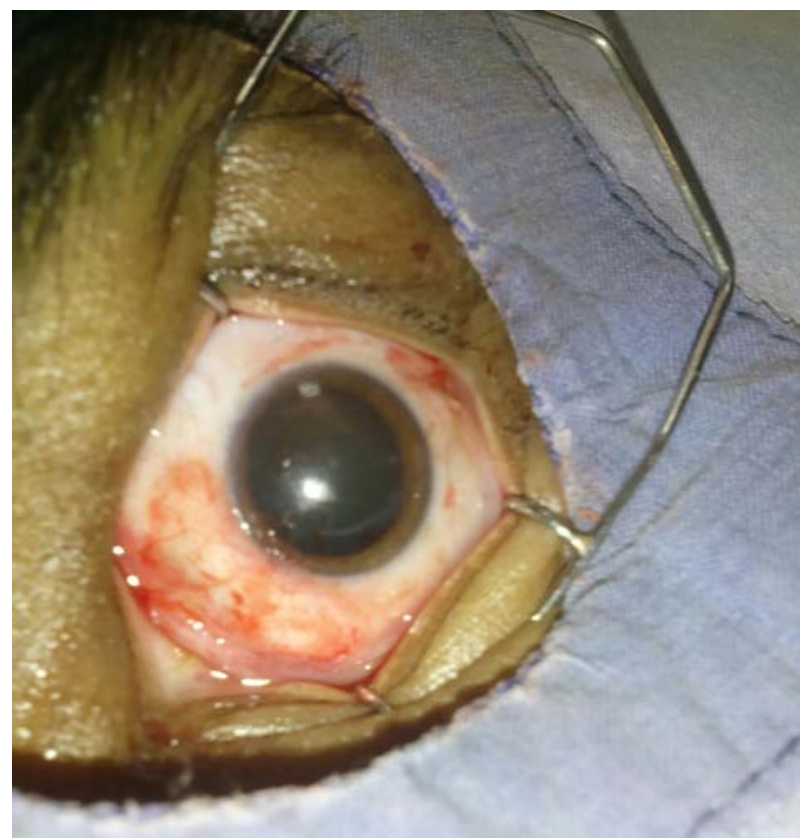

Figure 1. Limbal subconjunctival Autograft fixation using autologous blood after pterygium excision
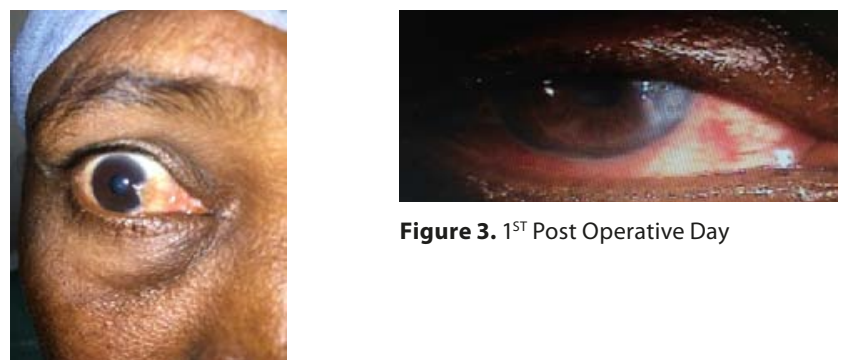

Figure 3. $1^{\text {ST }}$ Post Operative Day

Figure 2. Before Surgery
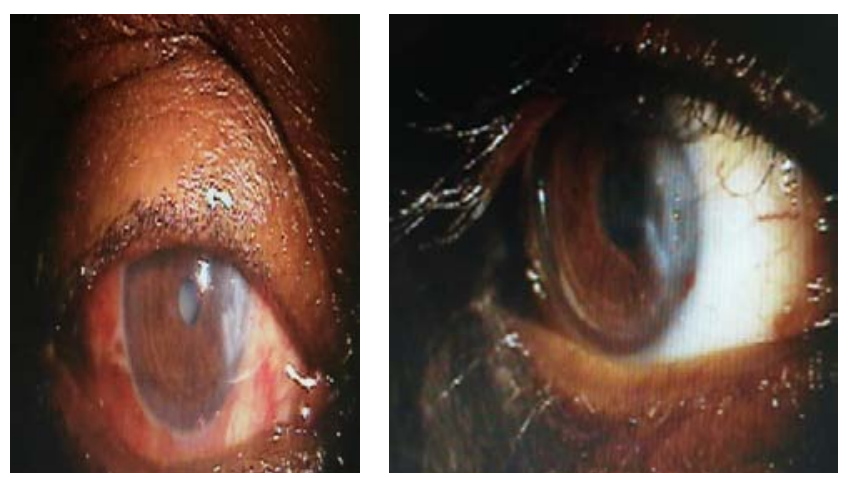

Figure 4. $7^{\text {th }}$ Post operative day

Figure 5. Post operative 6 weeks

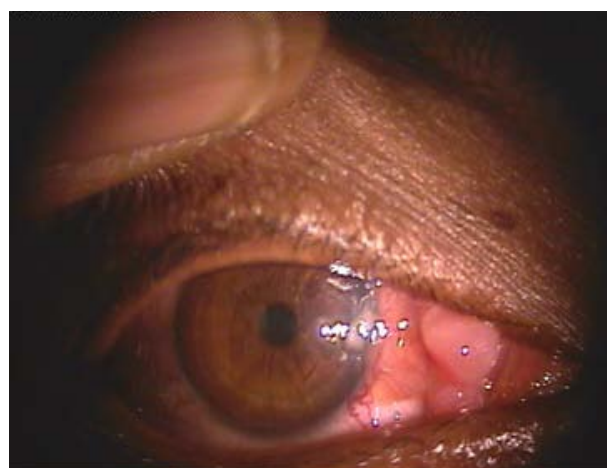

Figure 6. Granuloma 


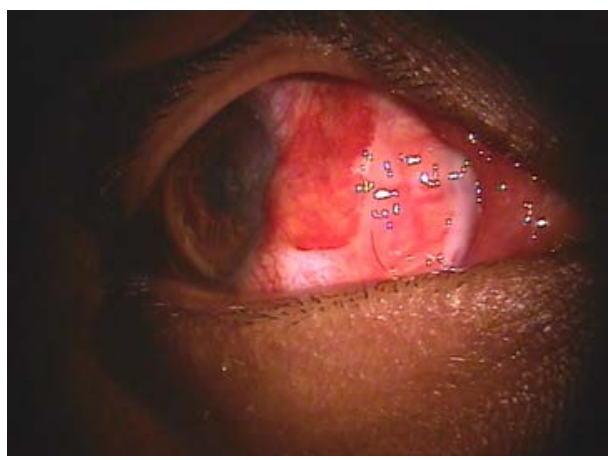

Figure 7. Inferior Border Graft Retraction And Sub Conjunctival haemorrage beneath graft

Table 1. Post operative complications

\begin{tabular}{lc}
\hline Complication & No of patients \\
\hline Granuloma & 2 \\
\hline Conjunctival haemorrhage & 10 \\
\hline Graft dehiscence & 5 \\
\hline Graft retraction & 5 \\
\hline Graft edema & 4 \\
\hline Recurrence & 2 \\
\hline
\end{tabular}

management of pterygium vary, but the recurrence rate after successful excision remains a challenge. The aim of pterygium surgery is to excise the pterygium and prevent recurrence. However, there are very few clinical guidelines for treatment that lower the recurrence and complication rates. The variety of techniques range from the bare sclera procedure to more complex approaches, such as amniotic membrane transplantation and lamellar keratoplasty, including conjunctival autograft, and limbal conjunctival transplant, conjunctival flap, conjunctival rotation autograft surgery, cultivated transplant (ex-vivo expanded conjunctival epithelial sheet on an amniotic membrane substrate has been shown to achieve immediate epithelialisation of ocular surface, reduced post-operative inflammation and faster ocular rehabilitation). The procedure is especially useful for closing large surgical defects following excision of extensive pterygium. Various techniques, such as sutures, fibrin glue to fix the conjunctival autograft after pterygium excision, are available. Adjunctive therapies include Beta irradiation, thiotepa, 5-fluorouracil, daunorubicin, and mitomycin C.

Bare sclera excision (BSE) has has become obsolete due to an unacceptably high recurrence rate (40-60\%). BSE with perioperative MMC, preoperative subconjunctival injection, intraoperative application and postoperative drops yielded better outcomes, but the risk of complication has made this procedure less favourable. BSE with betairradiation has resulted in encouraging outcomes (13\% recurrences); however, it has toxic and serious complications. The most common type of autograft fixation is suturing, with the drawbacks of prolonged operating time, post-operative discomfort, suture abscesses, granuloma formation and recurrence due to suture irritation. The presence of sutures may lead to prolonged wound healing and fibrosis. Fibrin glue has been used as an alternative to sutures for securing the conjunctival grafts. A study has reported a recurrence rate of $5.3 \%$ for glue versus $13.5 \%$ for sutures, and suggested that the immediate adherence of the graft and lack of post-operative inflammation may inhibit fibroblast ingrowth and reduce the recurrence rate. The main issue in using commercial fibrin glue, despite the viral inactivation techniques, the transmission of an infectious agent, such as parvovirus B19 (HPV19) and prions is possible. Furthermore, anaphylactic reaction has been reported after the use of (TISSEEL) fibrin sealant which was due to bovine protein aprotinin.

The use of patients own autologous blood was based on the mechanism of blood coagulation, but should be used before fibrinolysis occurs as blood clots naturally, was developed with all the drawbacks eliminated.

\section{CONCLUSIONS}

In this study, evaluation of primary nasal pterygium excision with conjunctival autografting using autologous blood as tissue adhesive was carried out. From this study, it could be concluded that the use of autologous blood as a tissue adhesive for graft fixation is a useful alternative [9]. This procedure has excellent outcomes: it is safe, effective, more economical, with less patient discomfort and more patient satisfaction [10]. The potential risks associated with the use of fibrin glue and suture related problems are avoided in this technique. The study by Boucher et al showed higher recurrence with autologous blood [11].

\section{REFERENCES}

1. Hirst LW, Sebban A, Chant D. Pterygium Recurrence time.Ophthalmology 1994; 101: 755-8.

2. Steven G Kramer, MD editor diagnostic and surgical techniques survey of ophthalmology volume 33. July-August 1988; pg: 41.

3. Duke-Elder WS. System of ophthalmology. Vol 8, Part 1. London: Henry Kimpton, 1965: 573-83.

4. Sandford-Smith J. Eye diseases in hot climates. Bristol: ELBS/Wright, 1987: 104-5.

5. Timothy j. threlfal, MBBS, MPH, and dallas r. english, phd sun exposure and pterygium of the eye: a dose responsive curve American journal of ophthalmology September 1999 pg 280.

6. Moran DJ, Hollows FC. Pterygium and ultraviolet radiation:a positive correlation. BRr J Ophthalmology 1984; 68: 343.

7. Hirst LW. The treatment of pterygium. Surv Ophthalmol 2003; 48(2): 145-180.

8. D'Ombrain A. The surgical treatment of pterygium. Br J Ophthalmology 1948; 32: 65-70.

9. Singh, Punith K. MS, Singh, Subadra MS, Vyas, Chandrashekar MS, Singh, Manju MS; Conjunctival Autografting without fibrin glue or sutures for pterygium surgery; Cornea; 2013 volume 32 -issuel p. 104-107.

10. D de Wit, Athanasiadis, A Sharma and J Moore: Sutureless and glue free conjunctival autograft in pterygium surgery: a case series.Eye(2010)24, 1474-1477.

11. Boucher S, Conlon R, Teja S, Teichman JC, yeung S,Ziai S; Fibrin glue versus autologous blood for conjunctival autograft fixation in pterygium surgery. Can J Ophthalmol. 2015 AUG; 50(4): 269-272. 